\title{
'Flexible Hierarchies and Dynamic Disorder': the drug distribution system in Frankfurt and Milan
}

\section{LETIZIA PAOLI*}

Department of Criminology, Max Planck Institute for Foreign and International Criminal Law, Freiburg, Germany

ABSTRACT The paper reconstructs the illegal drug distribution system in Frankfurt and Milan, by synthesizing the findings of a study that was financed partially by the European Monitoring Centre on Drugs and Drug Addiction. It shows that in both cities the great majority of drug deals, even those involving large quantities of drugs, are carried out by numerous, relatively small, and often ephemeral enterprises. In other words, referring to Adam Smith's famous saying, the 'invisible hand of the market'-and no large-scale organization-runs the drug exchanges. A previous finding of Roger Lewis's pioneering studies on local drug markets is thus confirmed. 'Flexible hierarchies and dynamic disorder' - to quote the title of one of his articles on the matter-dominate the trading and distribution of the major illegal drugs in local (and probably not only local) Western European contexts.

\section{Introduction}

I first met Roger Lewis in the late 1980s, when he was investigating the heroin market in my Italian hometown, Prato, together with Pino Arlacchi. Arlacchi, whose seminar I attended at the nearby University of Firenze, had offered me the chance to participate in the fieldwork and thus to gain for the first time direct experience in ethnographic research. My official task was humble: collecting local newspaper clips on heroin matters. Being a 'native', however, I was allowed to assist Roger in carrying out interviews with drug users and dealers. And it was thanks to this experience that I learnt how to interview this category of people, who-constantly menaced by state repression-are usually (rightly!) mistrustful of those asking too many questions.

The investigation of Prato's heroin market (Arlacchi \& Lewis, 1989) belonged to a series of local heroin market studies that Pino Arlacchi and Roger Lewis carried out together in the second half of the 1980s in several Italian cities: among these were Naples (Arlacchi et al., 1985), Rome (Arlacchi \& Lewis, 1987), Crotone (Arlacchi et al., 1987), Verona (Arlacchi \& Lewis, 1988, 1990a), Bologna (Arlacchi \& Lewis, 1990b) and Reggio Emilia (Arlacchi \& Lewis, 1990c). It was only when I

\footnotetext{
* Correspondence to: Dr Letizia Paoli, Department of Criminology, Max Planck Institute for Foreign and International Criminal Law, Günterstalstraße 73, D-79100 Freiburg, Germany. Tel.: + 49 (0)761 7081-311. Fax: + 49 (0)761 7081-294. E-mail: 1.paoli@iuscrim.mpg.de
} 
got involved in an inventory of qualitative research in the European Union (see Fountain \& Griffiths, 1997), that I realized fully how innovative Arlacchi's and Lewis's drug market studies were. That inventory, in fact, showed that drug market research was quite underdeveloped even in countries where illegal drug consumption patterns are regularly investigated and monitored by academic scholars (such as the UK and the Netherlands). Indeed, up to the mid-1990s, Arlacchi and Lewis's studies on local drug markets constituted a real novum in the panorama of European drug research.

\section{The EMCDDA Project}

It was to fill this research gap that in early 1999 the European Monitoring Centre on Drugs and Drug Addiction (EMCDDA) in Lisbon launched a call for tenders to study local drug markets in five European cities. By that time, in fact, the awareness had spread that market analysis is an invaluable tool. In order to develop and implement realistic and thus effective drug policies, we need to know how a drug market works, who are its actors and how they interact with each other. Roger Lewis, who had worked at the EMCDDA since 1998, was instrumental in fostering that awareness and in promoting the above-mentioned study, being convinced that it could provide innovative scientific and policy insights. When the EMCDDA selected my proposal and entrusted the implementation of the first phase of the project to my current research institute, I was delighted to continue Arlacchi and Lewis's pioneer work and to do so in a transnational framework. The challenge was even more thrilling because I was given a chance to investigate not only local heroin markets, but urban illegal drug markets as a whole.

As I had already been working on organized crime in Milan and in Frankfurt, I chose to focus the first phase of the project on the local drug market of these two cities, which are respectively Italy's second and Germany's fifth largest. It was originally planned to extend the study to three additional cities during a yearlong second phase: Amsterdam, Copenhagen and Paris. However, owing to the unavailability of funds on the part of the EMCDDA, the second phase was cancelled and the study is now being concluded in Frankfurt and Milan (Paoli 2000b).

To reconstruct the evolution and functioning of local drug markets, a multifaceted methodology was developed which emphasizes qualitative research instruments and whose rationale-following Arlacchi and Lewis's lesson-is to collect information from as many different perspectives as possible. In particular, both primary and secondary sources have been used.

As far as primary sources are concerned, the research teams I set up in Frankfurt and Milan have collected first-hand information from the four main actors of today's illegal markets: consumers, suppliers, law enforcement personnel, as well as public and private drug treatment providers. In particular, during the first phase the two research teams carried out more than thirty in-depth interviews with law enforcement officials, public drug treatment providers, and the representatives of drug-related non-governmental organizations in each of the two cities. Additionally, 70 drug users and suppliers were interviewed in Frankfurt and 55 in Milan. In order to obtain standardized and comparable results, a questionnaire was developed. At both sites, more than half of the interviews with drug users and dealers were carried out by the core members of 
the two research teams, the rest by ad hoc recruited interviewers, some of whom had used and/or traded drugs themselves.

Four main secondary sources can be listed:

- existing studies, including grey literature;

- the periodical and ad hoc information released by local and national law enforcement agencies, drug treatment services, and other public bodies;

- criminal cases; and

- media articles and reports.

Besides reviewing all the existing publications and the grey literature on drug markets at the local, regional and national level, more than 50 criminal cases were collected in each of the two cities. These cases can be added to a considerable sample of drug-related criminal cases that were examined by Paoli and colleagues in both Milan and Frankfurt in previous research projects. Additionally, the articles published by Milan's and Frankfurt's main daily newspapers (Il Corriere della Sera and the Frankfurter Rundschau respectively) on the local drug markets from the early 1970s onwards were retrieved and are currently being analysed.

In December 1999, when I went to the EMCDDA to discuss the project's first progress report, Roger Lewis had very encouraging words for my work-it was to be the last time I met him. Although he could not read the first-phase final report (Paoli, 2000b), the study in Frankfurt and Milan confirms Lewis's previous research findings not least in one important point: 'flexible hierarchies and dynamic disorder' - to quote the title of one of his articles on the matter (Lewis 1994) - dominate the trading and distribution of the major illegal drugs in local (and probably not only local) Western European contexts.

\section{The 'Invisible Hand of the Market'}

The 'disorganized' (Reuter, 1983) nature of the illegal drug trade is caused by the constraints deriving from the illegal status of the drugs exchanged. In fact, because of this status, all illegal market actors-and particularly drug traffickers and dealers - are obliged to operate (1) without and (2) against the state.

(1) Since the goods and services they provide are prohibited, illegal market suppliers cannot resort to state institutions to enforce contracts and have violations of contracts prosecuted, nor does the illegal arena host an alternative sovereign power to which a party may appeal for redress of injury (Reuter, 1983, 1985). As a result, property rights are poorly protected, employment contracts can hardly be formalized, and the development of large, formally organized, enduring companies is strongly discouraged.

(2) All suppliers of illegal commodities-and specifically drugs-are bound to operate under the constant threat of being arrested and having their assets confiscated by law enforcement institutions. Each participant in the drug trade will thus try to organize his or her activities in such a way as to assure that the risk of police detection is minimized. Incorporating drug transactions in to kinship and friendship networks and reducing the number of customers and employees are two of the most frequent strategies that drug entrepreneurs employ to reduce their vulnerability to law enforcement efforts (Moore 1974: 15-31; Reuter, 1983, 1985). 
These constraints have so far prevented the rise of large, hierarchically organized firms to mediate economic transactions in the illegal marketplace. The factors promoting the development of bureaucracies in the legal section of the economy-namely the advantage deriving from economies of scale and specialization of roles-are outweighed in the illegal arena by the very consequences of product illegality. Owing to these constraints, within the drug economy there is no immanent tendency towards the consolidation of large-scale, modern bureaucracies.

In Frankfurt as well as in Milan, the great majority of drug deals, even those involving large quantities of drugs, seem to be carried out by numerous, relatively small, and often ephemeral enterprises. In other words, to quote Adam Smith's famous saying, the 'invisible hand of the market' - and no large-scale organization-runs the drug exchanges.

Some of these enterprises are family businesses: that is, they are run by the members of a blood family, who resort on an ad hoc basis to a net of non-kin in order to carry out the most dangerous tasks (Polizeipräsidium Frankfurt AM, 1996: 36). Caddy, a former Frankfurt wholesale dealer, recalls,

We were a small organization that I had built and was composed of six persons: relatives and very close friends. It was organized according to the drugs. My wife and I dealt hashish, my brother-in-law and his wife with cocaine, heroin and speed. A friend of mine and his wife sold drugs at lower levels. The group members had a differentiated clientele. Women were usually in charge of taking appointments. The organization broke down when my brother-in-law was arrested. (Interview FF69) [1]

Some enterprises are non-kin groups, which are formed around a (charismatic) leader and then manage to acquire a certain degree of stability and develop a rudimentary division of labour. As a German trafficker, interviewed in prison, explains 'there is a chief dealer who has God knows how many smaller dealers working for him on the street or in private settings' (Interview FF9). In Milan, at least during the 1980s and early 1990s, most retail distributors of heavy drugs were linked to a supplier in a stable way; that is, distributors received drugs from their dealers on a regular basis without paying for them or paying only a small advance and then brought the money back to the dealer when they received a new batch of drugs. The usual Italian expression to describe such a relationship is that each dealer had his own cavalli (i.e. horses). The spread of this relationship constitutes an interesting difference vis-à-vis Frankfurt, where most user-dealers have always been free to buy drugs from whom they want and usually have more than one supplier at any time.

In both contexts, many drug enterprises are 'crews', loose associations of people, which form, split and come together again as opportunity arises. In crews, positions and tasks are usually interchangeable and exclusivity is not required; indeed, many crew members frequently have overlapping roles in other criminal enterprises. One of the officers working in the Frankfurt Police's organized crime section, states,

The structures, the stable hierarchic structures or family structures that are frequent in Italy, do not exist in Germany. ... As far as organized crime in Germany is concerned, specialists talk about a net-structure 
(Netzstruktur) and this is a correct representation that we can prove in our investigations. If some people want to commit a crime, they look for people specialized in the required tasks; the latter are asked and eventually recruited. Afterwards, the booty is divided and each of them goes their own way. Very, very rarely you can find steady gangs, which for a long period commit a series of crimes. (Interview FC5)

This analysis is confirmed by an experienced wholesale dealer who maintains: 'there are no vertical drug trafficking structures in Germany. Only horizontal ones. This means: "I know this person", "let's make a deal"' (Interview FF21).

Even Southem Italian mafia families, whose members were deeply involved in large drug deals in Milan during the 1980s and early 1990s, do not seem to operate like monolithic productive and commercial units. On the contrary, their members frequently set up crews with a few other mafia affiliates or even with external people to make drug deals. This mixed composition often cut across the hierarchy of the mafia family, thus causing rivalries and grudges.

The teams set up by Southem Italian mafiosi are far from being stable working units that could be compared with the branch office of a legal firm. Their composition frequently changes depending on the moment when deals take place or on the availability of single members. After one or a few drug transactions some teams are disbanded, while others continue to operate for a longer time, eventually changing their composition to some extent (Paoli, 2000b; see also Paoli 2001a; Tribunale Civile e Penale di Milano, 1993, 1997).

\section{Ordinary People and Foreign Migrants}

In both cities, especially at the intermediate and lower level, many dealers work alone, either to finance their own drug consumption habits or, more rarely, to earn fast money. Most of these drug entrepreneurs have no contact whatsoever with the underworld and are often inconspicuous people, who can hardly be distinguished from the mainstream population. This type of drug entrepreneur is most frequently found at the retail level of cocaine, hashish and party drugs, above all in closed scene settings. Most of Raffaele's six cocaine suppliers, for example, are 'normal people, they deal to supplement their salary. They are all Italian and Milanese' (Interview MF24). Likewise, Giovanni's hash dealer is

a serious person, though it seems a bit funny to say that about a drug pusher, he is not a hot head, he reasons, he has a job, a girl-friend, two dogs, he is a body-building fan, he is as normal person, as I am: I smoke, he deals. (Interview MF20)

Not only are small drug quantities traded by people who are beyond suspicion; two of the largest cocaine importers who have been active in the Milanese area over the last few years were not mafia members, but merely belonged to the sphere of white-collar crime. The first was a Milanese, Umberto Orio, who invested money earned from loan-sharking in the drug business and was able to import 600-800 kilograms of cocaine directly from Colombia each time. The second one was a former bank manager from Naples, Pasquale Centore, who was responsible for several shipments each of 400-700 kilograms. Both of these people supplied a plurality of wholesale traffickers, including members of Southem 
Italian mafia groups, who resided in several parts of the country (Procura della Repubblica di Milano, 1999).

In both Milan and Frankfurt, the street drug market is dominated largely by foreign dealers, as police statistics and interviews with key witnesses, drug users and dealers point out. Within a few years a substitution process has taken place; the lowest and most dangerous positions, which used to be occupied by the most marginalized Italian/German drug users, are now taken by foreigners, especially those who have immigrated recently, are applicants for political asylum or do not have a residence permit. As Andrea, a 39-year-old former heroin and current crack user maintains, in the beginning my dealers were German, later on the situation changed, a Yugoslav came in and...now, on the cocaine market, they are Arab and African' (Interview FF32). The same evolution is also taking place in Milan; as a former Italian hash and cocaine dealer sharply puts it, 'ten years ago, the dealers were mostly Italian, now they are predominantly foreigners' (Interview MF22).

Like other forms of crime in the past, the involvement in today's largest illegal market is used by immigrants as a 'queer ladder of social mobility' (Bell, [1953] 1988). To a greater extent than in the past, migrants today have a harder time accessing the legal economy and, owing to the restrictive policies adopted by most Western European states, are more likely to find means of survival only in the informal and illegal economies. Many of them are also drug users, who have started to deal drugs in order to finance their consumption patterns.

\section{Short Distribution Chain, Open Markets}

In neither Milan nor Frankfurt has a person ever succeeded in controlling the city market for any illegal substance. This is the case although during the 1980s several mafia and underworld drug dealing enterprises operating in Milan tried to exercise monopoly claims over their areas of settlement, obliging the local intermediate and street dealers to buy drugs from them. None of these groups, however, ever succeeded in controlling the whole city market or even relevant portions of it. As the Chief of the Milan Police Narcotics Squad candidly put it, 'the market is free, the drug is not' (Interview MC6; see also MC10). The drug markets of both cities have always been open markets in which anybody can try to earn their fortune by selling, importing or producing drugs.

In Frankfurt in particular, the openness of the illegal drug market is guaranteed by the city's closeness to the Netherlands. Since the 1970s, dealers and users alike have been crossing the Dutch border to obtain illegal drugs. Among our interviewees, there were also several who used to make or still make such trips; many others buy (or bought) their doses from people who get their supplies from over the Dutch border. How easy it can be, is clearly described by Luigi, a part-time dealer, who regularly went to Amsterdam to buy ecstasy, amphetamines and LSD.

On a weekend night you can be in Amsterdam in four hours. You leave at 4 p.m. and arrive at 8 p.m. It is already dark, you can drive home very well. You are back at midnight or 1 a.m. You hand the drugs out or whatever. At 7 a.m. I go to work as usual. (Interview FF53; see also Interviews FF5, FF45, FF59, FF42) 
Indeed, many German respondents no longer seem to regard the Netherlands as a true 'foreign' country and consider it 'normal' to go there to buy drugs. Asked if they have ever bought drugs abroad, some respondents spontaneously answered no and, only after thinking about it twice, recalled that they had been in the Netherlands to buy heroin, hashish or other drugs (Interviews FF31, FF32, FF38 and FF21).

Given this widespread practice, the drug distribution chain in Frankfurt is often very short. Indeed, if the consumers themselves buy drugs in the Netherlands, they themselves become importers. Then there is strictu sensu no national distribution system at all, as all German wholesale and retail dealers are bypassed by these entrepreneurial user-importers. In any case, owing to the proximity of the Netherlands, a few transactions are sufficient to pass the illegal merchandise from the importer to the final user, even when the latter does not cross the border himself.

In Milan, too, illegal drugs arrive on the market through a plurality of different channels and the drug distribution chain is frequently much shorter than the sixlevel hierarchical model developed by Preble and Casey (1969) in the late 1960s for the New York heroin market. In both cities, the length of the distribution chain-that is, the number of transactions occurring between the importer and the final user-depends foremost on the amount of the substance imported and, secondarily, on the connections of the importer, the intermediate dealer(s) and the user. In some cases, there are numerous transactions and the drug distribution system tends to approach Preble and Casey's six-level hierarchical model. However, in most cases, especially in the market for party drugs but also increasingly in the heroin market, the distribution chain is much shorter and two, at most three transactions link the importer to the final users.

Even the heroin distribution system today is much shorter than it used to be. This is due to the fact that Kosovo Albanians, who presently play an important role in the heroin-smuggling business throughout Europe, no longer import as large quantities as many Turkish smuggling rings used to do. Albanians deposit the drugs in Eastern European countries and let heroin be smuggled into the European Union by Western European couriers, who travel with Western European cars carrying relatively small quantities of drugs. These lots of heroin are quickly distributed and, with at most two transactions, reach the final users (Procura della Repubblica di Milano, 1998). As a Milanese police officer put it, 'the Albanian importer sells heroin in Italy to the North African dealer, who buys half a kilogram and re-sells it to the pusher. The latter supplies the end-customer (Interview MC2: see also Interviews MC10, and MC11).

Far from being a blueprint, the six-level hierarchical model developed by Preble and Casey seems to be only one of the possible forms a city drug market may assume. Moreover, even when this model works, it is worth remembering that individuals and groups may quickly change positions within it or play different roles in the distribution chain of different drugs. The crew headed by Salvatore Di Marco and Antonino Guzzardi, two Sicilian Cosa Nostra members living in Milan, for example, was able to import cocaine directly from Colombia in 100-kilogram lots. At the same time, however, the leaders of the crew used to sell one or two kilograms of heroin to a plurality of smaller dealers (Tribunale Civile e Penale di Milano, 1996).

At both sites empirical evidence additionally shows that the relationships between drug dealing enterprises are closer to competition than to collusion. 
Although some suppliers may occasionally enjoy a considerable monopolistic power over a local (usually small) market, in Frankfurt as in Milan, most drug enterprises seem to be price-takers rather than price-givers. That is, none of them is able to influence the commodity's price appreciably by varying the quantity of the output sold. It is not by chance that the wholesale and retail prices of all the main substances-with the exception of cannabis-have steadily decreased in both contexts throughout the past two decades. This decline has been accompanied by a comparable fall in purity levels. Only cannabis prices are reported stable in Frankfurt and increasing in Milan. Apparently following international trends, the prices for all the main illegal substances are strikingly similar in both cities, though slightly higher in Milan than in Frankfurt (Paoli 2000b).

Given this, the conclusions that Roger Lewis drew from his heroin trading studies are still valid and, indeed, may be extended to the illegal drug market as a whole:

The resilience and adaptability of the heroin delivery systems described above, in the face of the sustained enforcement pressure, raises questions as to the usefulness of contemporary prohibitionist models of controls. It is possible that a formally regulated and taxed market might lead to a reduction in the drug-related harm, revenue-raising crime and violence that are associated with illicit heroin economies. The fact that such a taboo subject is now a matter for lively debate suggests that in Europe, if not the United States, the regulation of drug markets is being seen as a practical policy issue rather than just one more business opportunity for moral entrepreneurs. (Lewis, 1994: 53)

\section{Note}

[1] All interviews with public and private drug treatment providers, law enforcement officials as well as users and dealers are kept anonymous and are referred to with a code (for example MF1 or FA1). The first letter of the code refers to the city: $M$ for Milan and $F$ for Frankfurt. The second letter points to the specific background of the interviewee: A for representatives of public drug treatment centres; B for representatives of private drug treatment centres; $C$ for police and prison officials; $D$ for prosecutors; $E$ for judges; F for users and dealers. Finally, to distinguish interviews with people of the same category, a progressive number has been added according to the interview's date and/or its transcription's arrival at the Max Planck Institute.

\section{References}

Arlacchi, P. \& Lewis, R. (1987). Analisi del mercato delle droghe pesanti e sua influenza ai fini della determinazione della categoria giuridica della modica quantità. Rome: Ministry of Justice.

Arlacchi, P. \& LeWIS, R. (1988). Il mercato dell'eroina a Verona e provincia. Verona: Unità Squitaria Locale 25.

Arlacchi, P. \& Lewis, R. (1989). Il mercato dell'eroina a Prato e hinterland. Prato: Comune di Prato.

Arlacchi, P. \& LeWIS, R. (1990a). Imprenditorialità illecita e droga. Il mercato dell'eroina a Verona. Bologna: Il Mulino.

Arlacchi, P. \& Lewis, R. (1990b). Droga e criminalità a Bologna. Micromega, 4, pp. 183-221.

Arlacchi, P. \& Lewis, R. (1990c). Il mercato dell'eroina a Reggio Emilia e provincia. Reggio Emilia: Provincia di Reggio Emilia. 
Arlacchi, P., Lewis, R. \& Pizzorno, A. (1985). Camorra, contrabbando e mercato della droga in Campania. Rome: Parliamentary Anti-mafia Commission.

Arlacchi, P., Lewis, R. \& Turi, G. (1987). Il mercato della droga a Crotone. Crotone: Comune di Crotone. Bell, D. ([1953] 1988). Crime as an American way of life. In D. Bell, The End of Ideology (pp. 127-50). Cambridge, MA: Harvard University Press.

Fountain, J. \& Griffiths, P. (Eds) (1997). Inventory, Bibliography and Synthesis of Qualitative Research in the European Union, 3 vols. London: National Addiction Centre.

LEwIS, R. (1994). Flexible hierarchies and dynamic disorder-the trading and distribution of illicit heroin in Britain and Europe, 1970-90. In J. Strang and M. Gossop (Eds.), Heroin Addiction and Drug Policy. The British System (pp. 42-54). Oxford: Oxford University Press.

Moore, M.H. (1974). The Effective Regulation of an Illicit Market in Heroin. Lexington: Lexington Books. PAOLI, L. (2000a). Fratelli di mafia: Cosa Nostra e 'Ndrangheta. Bologna: Il Mulino.

PAoli, L. (2000b). Pilot Project to Describe and Analyse Local Drug Markets — First Phase Final Report: Illegal Drug Markets in Frankfurt and Milan. Lisbon: EMCDDA.

PolizeIPRÄSIDIUM Frankfurt, A.M. (1996). Rauschgift Kriminalität: Lagebericht 1995. Frankfurt aM: Polizeipräsidium Frankfurt aM.

Procura della Repubblica di Milano (1998). Richiesta per la applicazione di misure cautelari nei confronti di Generali Gerti + 3. Milan: January 29.

Procura della Repubblica di Milano (1999). Le dichiarazioni di Centore Pasquale. Estratto della requisitoria del P.M. Giuseppe D'Amico.

Preble E. \& CASEY, J.J. (1969). Taking care of business, the heroin user's life on the street. International Journal of Addiction, 4, pp. 1-24.

Reuter, P. (1983). Disorganized Crime. The Economics of the Visible Hand. Cambridge, MA: The MIT Press.

Reuter, P. (1985). The Organization of Illegal Markets: an economic analysis. Washington: National Institute of Justice.

Reuter, P. \& HaAga, J. (1989). The Organization of High-Level Drug Markets: an exploratory study. Santa Monica: Rand.

Tribunale Civile E Penale di Milano (1993). Ordinanza di custodia cautelare in carcere nei confronti di Agil Fuat + 164. Milan: October 2.

Tribunale Civile E Penale di Milano (1996). Sentenza nella causa penale contro Avalos Osorio Jorge Enrique + 23. Milan: February 17.

Tribunale Civile E Penale di Milano (1997). Sentenza nella causa penale a carico di Agil Fuat + 132. Milan: June 11 . 
Copyright of Drugs: Education, Prevention \& Policy is the property of Carfax Publishing Company and its content may not be copied or emailed to multiple sites or posted to a listserv without the copyright holder's express written permission. However, users may print, download, or email articles for individual use. 